(Issued-Aug. 30, 1983)

\title{
ECOLOGY AND SYSTEMATICS OF THE CLADOCERA (DAPHNIDAE: BRANCHIDPODA) INHABITING PUNJAB, INDIA
}

with 26 Text-figures

by

S. K. BAtTish

(Department of Zoology, Punjab Agricultural University, Ludhiana, India)

インド・プンジャブ地方に生息するミジンコ科（枝角亜目：

鰓脚目）の分類と生態

插図 26

S.K. バティシュ

(プンジャブ農業大学動物学教室)

\begin{abstract}
Nine species of Cladocera belonging to family Daphnidae are discussed and illustrated, along with their ecology, from Punjab, India. The assemblage includes: Daphnia lumholtzi SARS, D. magna Straus, D. similis Claus, Simocephalus acutirostratus KING, S. expinosus (KOCH), S. vetulus (O.F. MÜller), Scapholebris kingi SARS, and $C$. reticulata JURINE.
\end{abstract}

\section{Introduction}

In the present paper, the author wishes to publish ecological data and short illustrated descriptions of nine species of Cladocera belonging to family Daphnidae, based upon over 1000 samples collected from all over punjab during the last several years. In an earlier publication (BATTISH, 1981) account of the twelve chydorid and macrothricid species has already been published.

For the literature on Indian Cladocera, location of Punjab, material and methods and repository of material the readers are advised to consult BATTISH (1981).

Ecology: In Punjab, Cladocera constitute the bulk of zooplankton especially in ponds and littoral zones of lakes and slow moving brooks rich in vegetation. In these ecosystems, Cladocera function both as biophages as well as saprophages, hence are very important links in the food chains. Being the feeders of dead organic matter, it is little surprising that they occur in the organically polluted habitats and are known to play a role in the self-purification of polluted habitats; Moina dubia, has rightly been called as 
the "living bacterium-detritus filter" (LEODOLFF, 1964). Unfortunately, studies on these lines are fragmentary and still at the almost beginning. However, comments on the ecology of Indian Cladocera can be found in the publication of PRUTHI (1933), Ganapati (1943), Das and Srivastava (1956, 1959), Chakrabarty et al. (1960), Moitra and Bhattacharya (1965), George (1966), Battish (1968, unpublished), Vasisht and Dhir (1970), SReenivasan (1967, 1972, 1974), NASAR (1975), Khan \& Quyyum (1978), Vass \& Zutshi (1980) and Battish \& Parminder (in press).

Daphnia lumholtzi SARS, 1885

(Figs. 1-6)

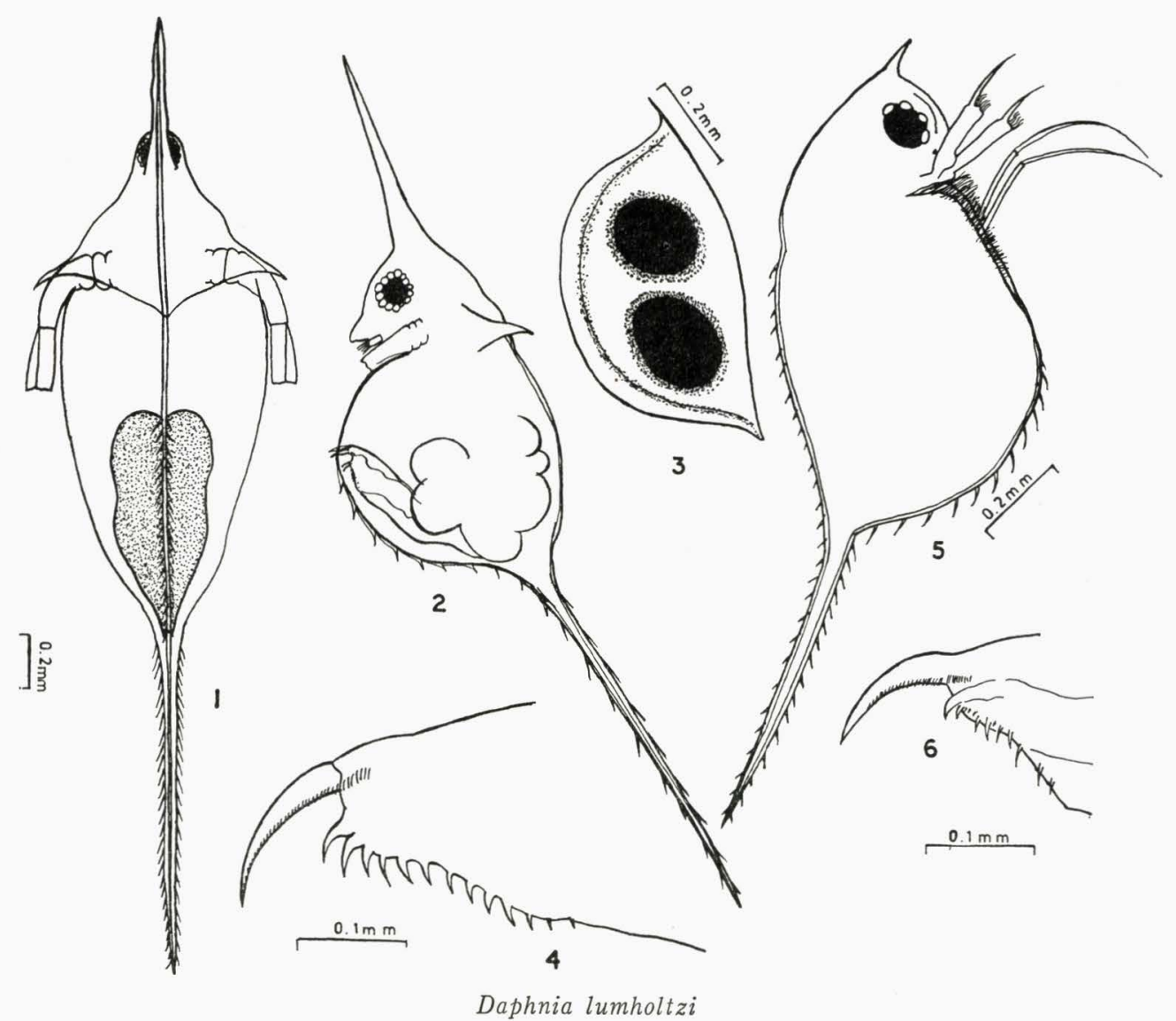

Fig. 1. Female, dorsal view

Fig. 2. Female, lateral view

Fig. 3. Female, postabdomen

Fig. 4. Ephippium

Fig. 5. Male, lateral view

Fig. 6. Male, postabdomen 
Measurements*: 우 우 Carapace length $=0.8-1.0 \mathrm{~mm}$.

oิ \& Carapace length $=0.7-0.8 \mathrm{~mm}$.

Locality: This species was collected on 17.3.1968 from Rajindra Tank, Patiala, which is located at the Mall-Station Road, Opposite to Public Central Library.

Remarks: D. lumholtzi is morphologically fairly uniform species. It can easily be distinguished by its almost oval carapace having about $8-12$ strong spines on the ventral margin and the anteriorly projecting spike-shaped crest on the head (may be reduced in some forms). The postabdomen is with weakly sinuate dorsal margin bearing 10-13 anal spines. In the material at hand all the forms had well developed anteriorly projecting crests and two lateral spines.

Males are smaller than females. Head is conspicuously separated from the carapace by an indentation above heart. Head crest is usually smaller than that of female. Antinnules are well developed and are nearly as long as head. At the antennular tip a strong and somewhat curved flagellum is present, besides bristles. Postabdominal dorsal margin sinuate and bearing one strong spine and upto 8 small spines.

Ecology and distribution: D. lumholtzi which was described from Australia by SARS in 1885 is wide spread in its distribution. It has been reported from lakes and large reservoirs in both coastal and inland areas of Queensland, N.S. WhALES and Victoria in Australia (HEBERT, 1977). This species has also been recorded from Africa (DADAY, 1910) and Asia (Gurney, 1916; Bay, 1924 ; Arora, 1931; Fernando, 1980). In India it has been reported from ponds and lakes of Rajasthan (NAYAR, 1977), and Blihar (NASAR, 1977). It was collected from the Rajindra Tank, Patiala at a temperature of $20^{\circ} \mathrm{C}$ and $\mathrm{pH} 7.2$ in the month of March, 1968. At the time of collection the tank was very rich in aquatic vegetation and had a depth of 1.5 meters.

According to BROOKS (1957) D. lumholtzi do not occur in the New World.

\section{Daphnia magna STRAUS, 1820}

(Fig. 7)

Measurements: 우 우 Carapace length $=2.9-3.2 \mathrm{~mm}$.

Locality: This species was collected from a pond at Khera Jattan (Patiala) in November, 1967 and January, 1968 and a pond at Sunet (Ludhiana) on 16.12.1980.

Remarks: Body of female D. magna is subovate thick and translucent. The head is compressed with a moderately developed rostrum, obtuse at tip. Eye is prominant but ocellus small. Antennnules are small and olfactory setas do not extend beyond rostrum. Carapace spine is well developed. This species can easily be distinguished from $D$. similis on the basis of deeply sinuate dorsal margin of postabdomen, bearing a

* Only reproductives measured; for all the species of Daphnia only Carapace length is given. 


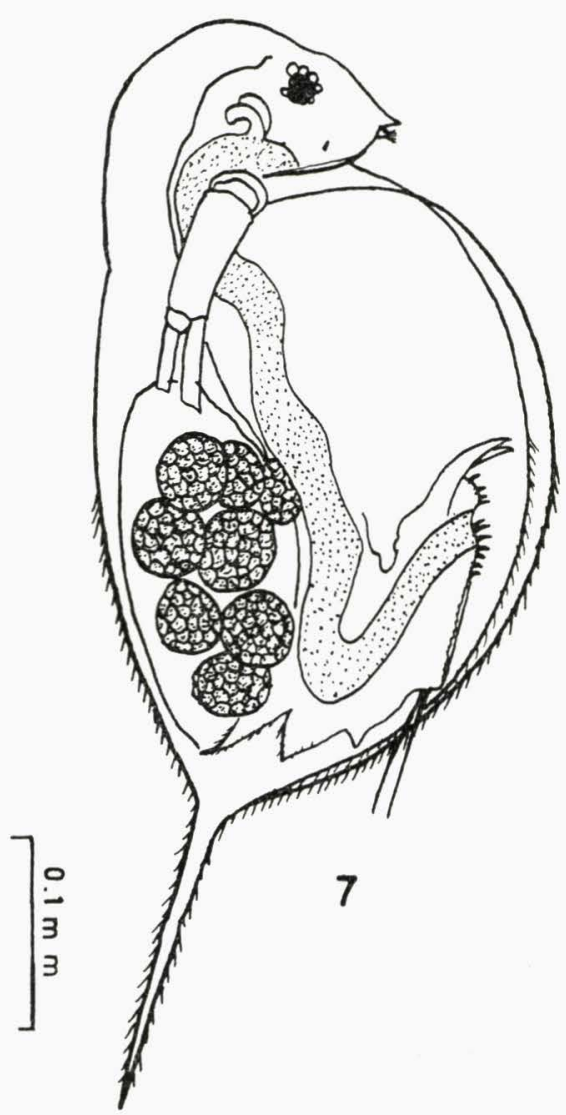

Daphnia magna

Fig. 7. Female, lateral view

proximal set of 7 and distal set of 4 spines. Ephippial forms were not present in the collections.

Ecology and distribution: According to BROOKs (1957) D. magna enjoys a wide distribution in the old world, occurring sporadically over most of Eurasia and Africa, north of Sahara. The present investigation reveals that it occurs rarely in Punjab. It was found to occur in a pond at village Khera Jattan (Patiala) during November, 1967 and January, 1968; however, the conditions were favourable on 12.11.1967 at a temperature of $20.5^{\circ} \mathrm{C}$ and $\mathrm{pH} 6.7$ as it was found in maximum number. This species is known to occur in India at a height of $1585 \mathrm{~m}$ as reported by BREHM (1936) from Phashakuri (Kashmir).

\section{Daphnia similis Claus, 1876}

(Figs. 8-12)

\section{Measurements: 우우 Carapace length $=1.32-$ $1.4 \mathrm{~mm}$. 今ิ Carapace length $=0.8^{-}$ $1.2 \mathrm{~mm}$.}

Locality: D. similis is the commonest species of Daphnia found in Punjab, has been collected from quite a good number of habitats. It was first collected in 1967-68 in ponds and tanks at Patiala and afterwards a number of localities in other districts. To mention some of these: a pond at Manakwal (Lundhiana) on 28.6.1974, small ditch at Haibowal (Ludhiana) on 21.2.1976, Gill and near Dugri (Ludhiana) on 20.12.1976, Pondori Village (Ludhiana) on 18.8.1980 and Sandhwar (Faridkot) on 21.9.1980. The present author studied its seasonal abundance in a pond at village Khera Jattan (Patiala) in 1967-1968 and BATTISH and PARMinder studied its seasonal abundance in a pond at Raqba (Ludhiana) in 198081.

Remarks: This thick bodied form like D. magna has a head and carapace of normal size and shape but the two forms can easily be differentiated on the basis of postabdomen. In $D$. similis, the dorsal margin of postabdomen, in contrast to D. magna is not sinuate and is with 10 to 12 anal spines. The postabdominal claws bear two distinct combs. The ephippium is dark brown, subrectangular carrying two obliquely 


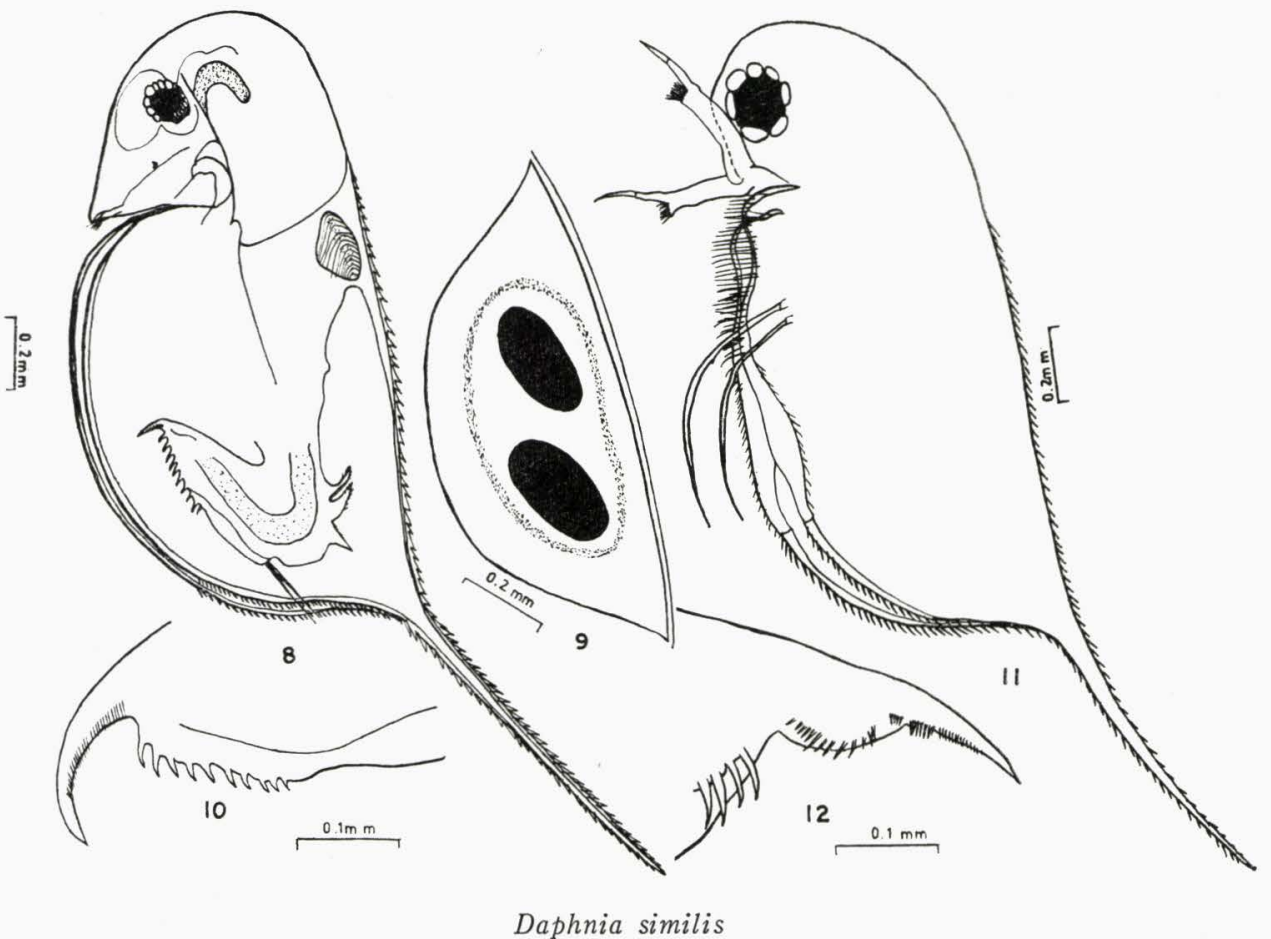

Fig. 8. Female, lateral view

Fig. 9. Ephippium

Fig. 10. Female, postabdomen

Fig. 11. Male, lateral view

Fig. 12. Male, postabdomen

directed eggs. Males are smaller than females. The head is large but with reduced rostrum. Eye is prominent than that of female. Antennules are long with flagellum of moderate size. Carapace is broad bearing spinules on almost entire dorsal margin. First leg is with a hook and flagellum like the males of other species. Dorsal margin of postabdomen is sinuate, as also pointed out by BROOKS (1957) this sinuosity appears due to a rounded bulge at the base of the claw.

Ecology: As mentioned above (in Locality) this is the commonest species of Daphnia in Punjab. It was collected during the different months and in habitats ranging from small shallow ditches to the large ponds having water expanse of about 5 acres. It has been collected from waters ranging in $\mathrm{pH}$ from 6.0-9.4. Seasonal abundance of this species was studied by the present author in a pond at Khera Jattan (Patiala) in 1967-68. In this pond the female D. similis occurred from November 26, 1967 to May 12, 1968, between a range of temperature of $16.0^{\circ} \mathrm{C}$ to $27.0^{\circ} \mathrm{C}$. However, the population reached its peak on 7.1 .1968 at a temperature of $16.0^{\circ} \mathrm{C}$ and $\mathrm{pH} 6.1$. BATTISH and Kumari (in press) studied the population dynamics of Cladocera in a pond at Raqba (Ludhiana). 
These authors found $D$. similis in maximum number on 15.1 .1981 at a temperature of $14.0^{\circ} \mathrm{C}$, S.D. T. $25.6 \mathrm{~cm}, \mathrm{pH} 8.23$, DO $2.5 \mathrm{ppm}$ and $\mathrm{CO}_{2} 32.0 \mathrm{mg} / \mathrm{L}$.

According to BROOKS (1957) D. similis is old world in origin and is widely distributed over the globe. Though it can adjust to strongly saline water, yet is restricted to the marginal habitats where predation and competition is weak.
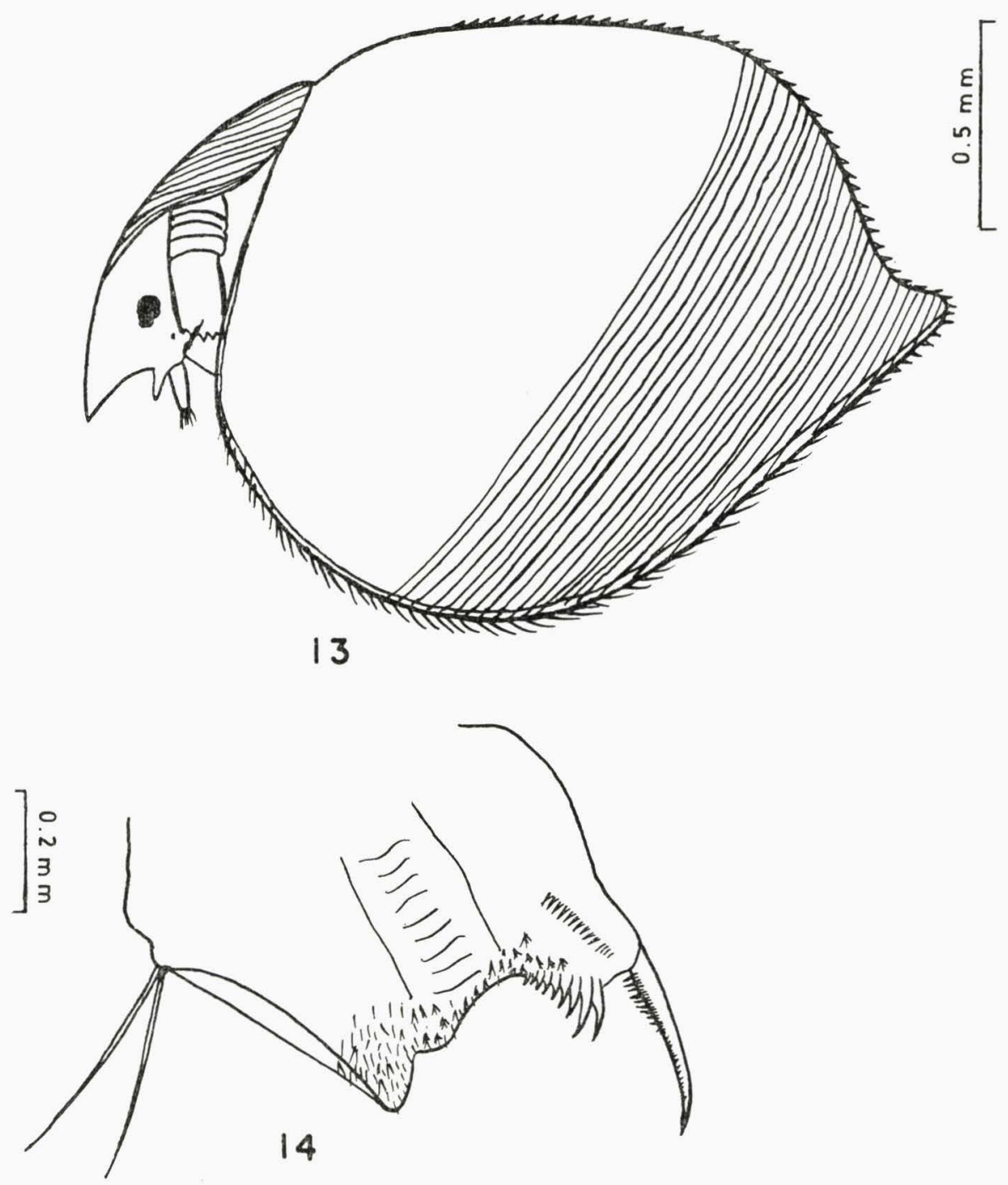

Simocephalus acutirostratus

Fig. 13. Female, lateral view

Fig. 14. Female, postabdomen. 
Simocephalus Schodler, 1858 (=Simosa Norman, 1903)

Simocephalus acutirostratus KING

(Fig. 13, 14)

Measurements: 우 우 Length $=1.8-1.9 \mathrm{~mm}$.

Locality: This species was collected from a pond at Bhaiwala, $5 \mathrm{~km}$ from Ludhiana on Ludhiana-Pakhowal road on 30.8.1976 and 4.9.1976. This pond had a water expanse of 3 acres and a depth of 2 feet at the times of collection.

Remarks: This species can easily be distinguished from other species of Simocephalus on account of head which is with an acute vertex. Head and rostrum like other species are small. Shell projects posteriorly in a blunt projection. Spinules are present on the mid dorsal line almost on the entire length and extend upto the posterior projection. Shell valves translucent and have parallel oblique lines all over. Unlike S. vetulus (O. F. MÚlLLER) very fine bristles are present on the ventral margins of valves. Postabdomen is broad having 9 or 10 anal spines. Claw is long and slender and having a pectin of about 13 teeth and with fine bristles on the concave side.

Ecology: This species, which is being recorded for the first time from India, was collected from a single habitat having shallow water (see locality).

During the period of its occurrence the pond harboured ostracods: Bharatcypris mackenzie BATTISH, Pseudocypris patialaensis BATTISH, Stenocypris major BAIRD, Cypris pubera O.F. MÚlLER and Strandesia vittata (SARS); oligochaetes; water beetles and water mites. The water was green in colour and part of the pond was covered with the green scum.

FERNANDO (1980) reported this species from ponds and reservoirs (anea $300 \mathrm{hac}$ ) of Sri Lanka. This species is also known to occur in the paddy fields (see MAMARIL and FERNANDO, 1978).

\section{S. expinosus (KocH), 1841}

(Figs. 15-17)

Measurements: 우 우 $=1.5-2.2 \mathrm{~mm}$.

Locality: This species was collected on 21.6.1968 from the Government Fish Farm Tanks, Chandigarh. These tanks are located near the escape channel of Sukhna Lake.

Remarks: S. expinosus (KocH) 1841 and S. vetulus (O. F. Múller) 1776 are very closely related species but differ in shape of carapace and armature of the postabdomen. In the former the posterior spine of carapace is almost missing, postabdominal claw has a pecten of 8 to 12 teeth at its base but in the latter posterior end of the carapace is produced into an obtuse angle and the claw is without pecten but having fine bristles 


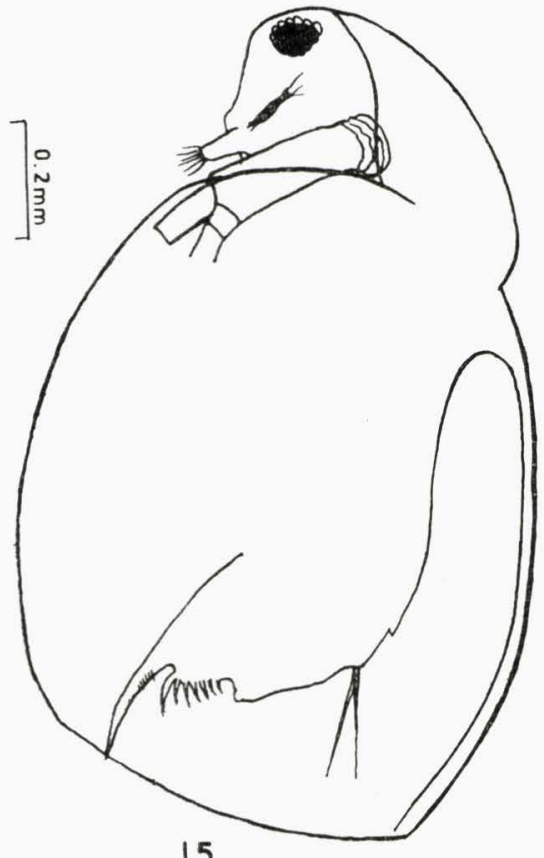

15
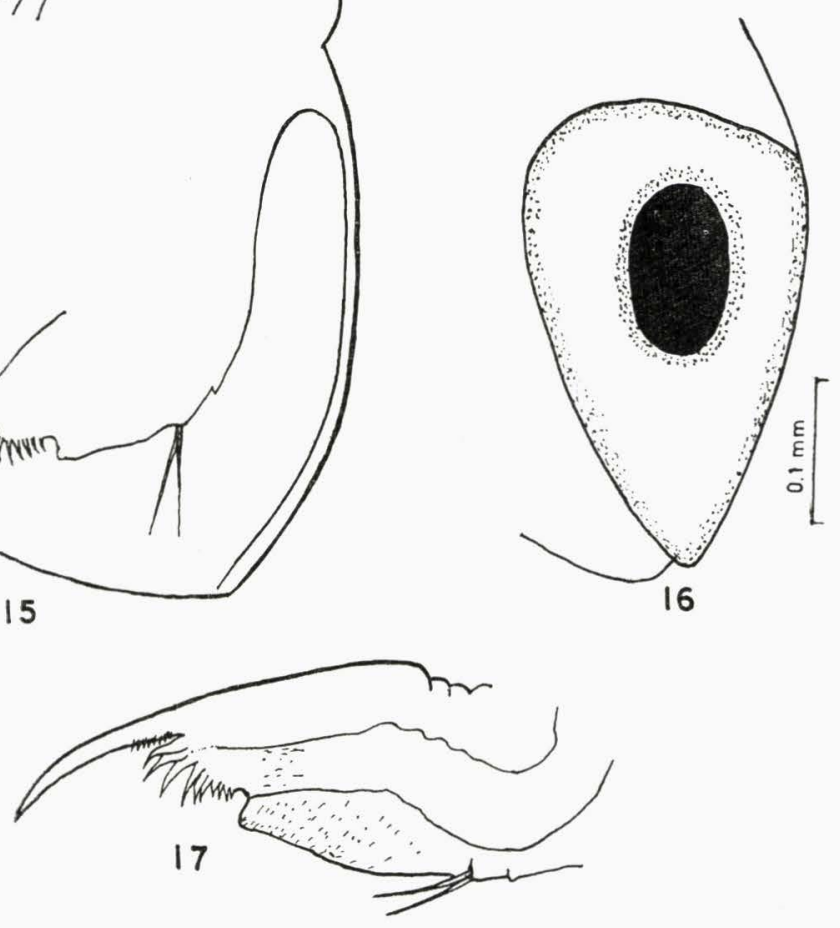

Simocephalus expinosus

Fig. 15. Female, lateral view

Fig. 16. Ephippium

Fig. 17. Female, postabdomen.

almost along entire length.

Ecology: Present is the first record of S. expinousus from India. This species is much more restricted in its distribution. It was collected from Chandigarh in the month of March, 1968 when temperature varied from 22.5 to $27.0^{\circ} \mathrm{C}$ and $\mathrm{pH} 7.3-7.9$.

\section{S. vetulus (O. F. MÜller) 1776}

$(=S$. vetuloides SARS)

(Figs. 18, 19)

Measurements: + 우 Length $=1.6-1.8 \mathrm{~mm}$.

Locality: This is the commonest species of Simocephalus in Punjab, has been col- 


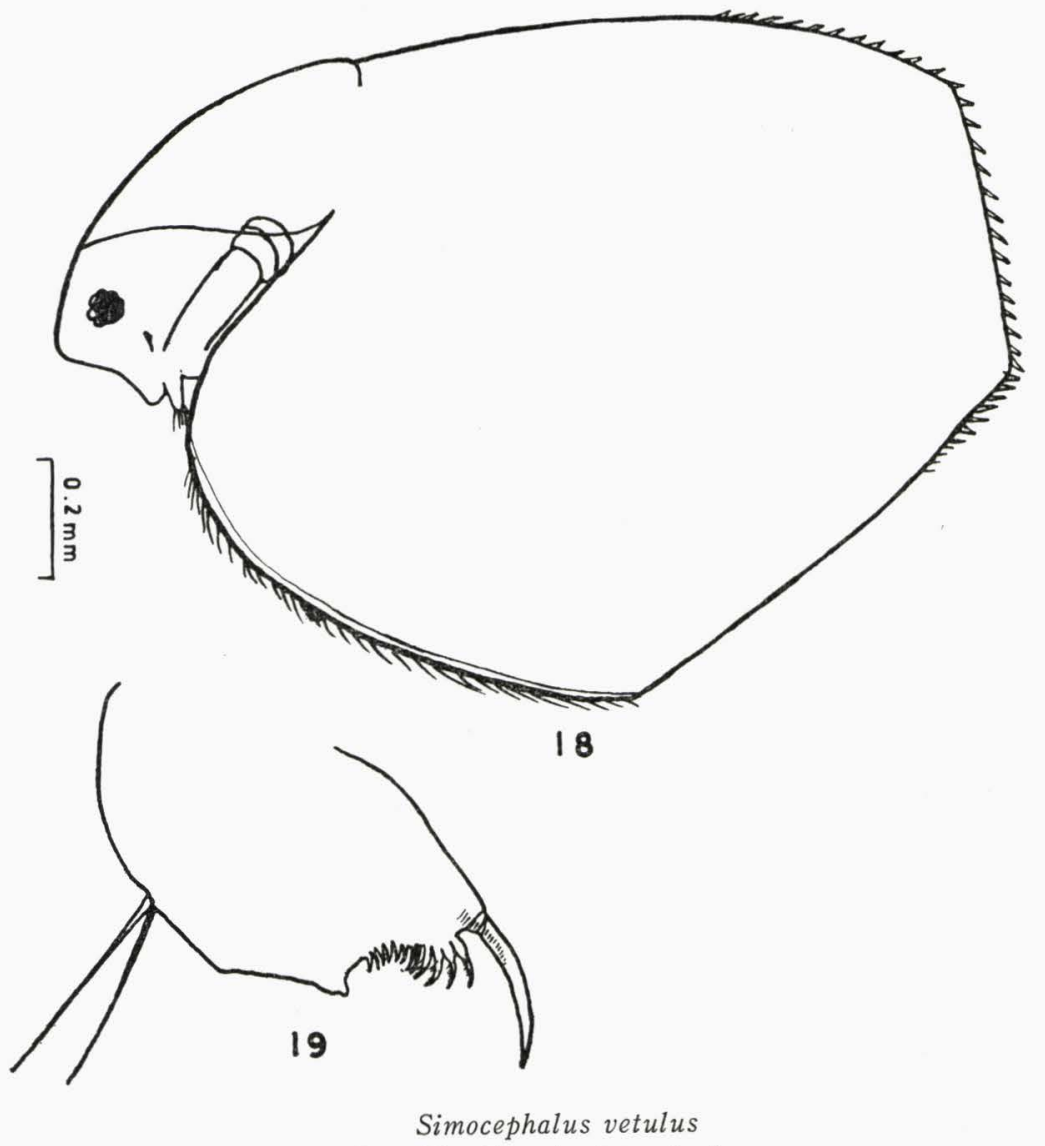

Fig. 18. Female, lateral view

Fig. 19. Female, postabdomen.

lected from almost all the districts of Punjab.

Remarks: Although SARS (1917) upheld the identity of S. vetula O. F. MÚLLER and S. vetuloides SARS as separate species on the basis of the carapace yet the present author prefers to treat these as synonyms, following JOHNSON (1953) and FRYER (1957). The species name $S$. vetulus should be preferred over $S$. vetula, but the credit must be given to O. F. MÜller.

This cosmopolitan species can be identified due to its rhomboidal shape, rounded vertex, elongated ocellus and broad postabdomen and absence of pecten on the claw.

Ecology: This cosmopoliten species can naturally tolerate wide range of ecological parameters. It is known to prefer the weedy waters, however. As observed by the present author (BATTISH, 1968) it reached its peak on 21.1.1968 at a temperature of $17.5^{\circ} \mathrm{C}$ and $\mathrm{pH}$ 6.7. Earlier Indian records of this species are from Ladakh (BREHM, 1936), Delhi (Brehm, 1950; George, 1966), Rajasthan (NAyar, 1971), Madhya Pradesh 
(SiNGH, 1982) and Bihar (NASAR, 1977). It has been found to inhabit water bodies of different types ranging from small-road side ditches, small cesspool with clean water (Botanical garden, Punjab Agricdltural University, Campus), tanks (Rajindra Tank, Sudhasur Tank, Motibagh Lake, all in Patiala), Lake (Bhupindra Sagar, Patran) and slow moving waters (Budha Nullah, Ludhiana).

\section{Scapholebris kingi SARS, 1903}

(Figs. 20-22)

Measurements: 우 ㅇ length of body $=0.71-0.73 \mathrm{~mm}$.

今 Length of body $=0.40-0.50 \mathrm{~mm}$.

Locality: This species was collected from Rajindra Tank on 21. 6. 1968, pond at Khera Jattan (population dynamics 1967-68), Sundhasur Tank (all in Patiala), Kapurthala on 13.1.1973 and Ludhiana 18.12.1980.

Remarks: This species can be easily identified due to its dark (almost black) and rounded rostrum and postero-ventral spines on the carapace valves. Postabdomen is short but broad, rounded at posterior end and bears 5-6 anal spines. The ephippium is
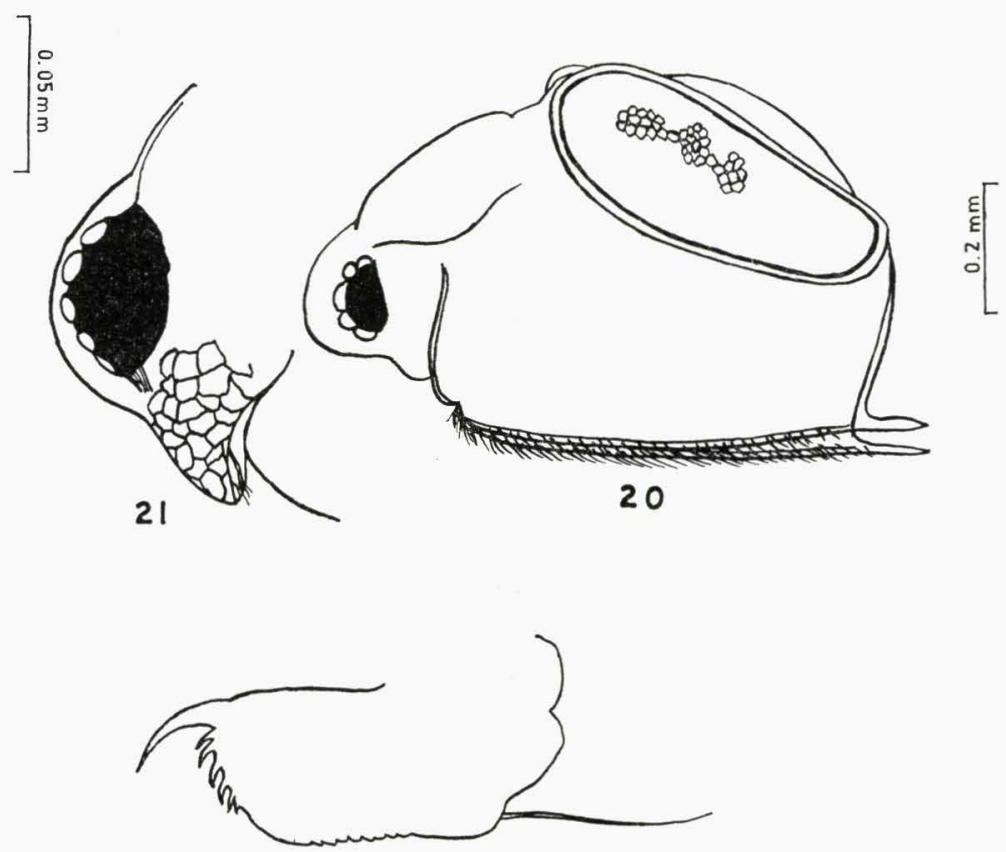

22

Scapholebris kingi

Fig. 20. Female, lateral view

Fig. 21. Female, head

Fig. 22. Female, postabdomen. 
dark-brown and carries a single egg.

Ecology: This species is known to occur in all types of habitats such as ponds, villus, rice fields, reservoirs 300 ha and miscellaneous habitats (FERNANDO, 1980). It is a eurythermal as it has been collected both during the summer as well as in winter months. But the dresent author found it in a peak population in pond at village Khera Jattan (Patiala) on 21.1.1968 at a temperature of $17.5^{\circ} \mathrm{C}$ and $\mathrm{pH}$ 6.7. During the present study it was found to occur in stagnant waters as well as littoral zones of slow running water. It prefers the upper part of water.

Ceriodaphnia cornuta SARS, 1888

(=C. rigandi RICHARD, 1894)

(Figs. 23, 24)

Measurements: 우 우 Length $=0.54-0.55 \mathrm{~mm}$.

Locality: This species has been collected from number of habitats: Bhupinder Sagar (Patran) on 17.5.1967, Khera Jattan (Patiala) 1967-68, Government Fish Farm Tank, Chandigarh from April-August, 1968, Gill pond (Ludhiana) on 11. 11. 1980, pond at Kotkapura 12.10.1980 and pond at Faridkot on 15.3.1981 and many other habitats.

Remarks: Now there seem to be be agreement that C. cornuta SARS, 1888 and $C$. rigaudi RICHARD, 1894 are the forms of the same taxon. SARS (1917) though agreed that $C$. cornuta is the variety of $C$. rigaudi but preferred the name $C$. rigaudi which, however, cannot be retained as the SARS's name has the priority.

Head is produced into pointed rostrum. Eye is quite large but ocellus is absent. Carapace is more or less oval but produced into a spine posteriorly. Body reticulate. Postabdomen is provided with 5-7 anal spines on the dorsal margin.

Ecology: Ceriodaphnia cornuta is the commonest species occurring in the Tropical

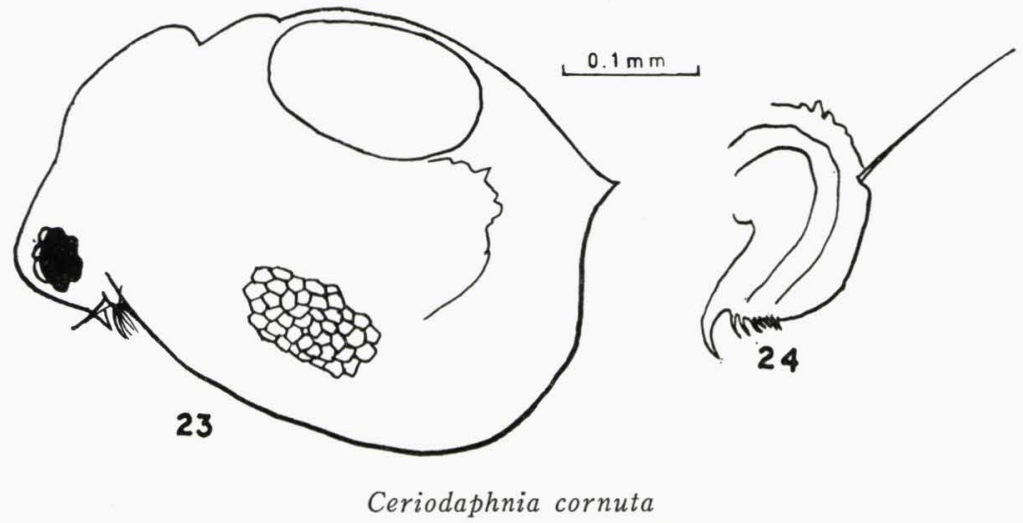

Fig. 23. Female, lateral view

Fig. 24. Female, postabdomen. 
zooplankton assemblage. This species is known to occur in the temporary and permanent ponds, rice-fields, flood lakes, reservorirs and rivers and streams (FERNANDO, 1980). In Punjab this species has been collected from different types of habitats ranging in temperature, $20.5-26.0^{\circ} \mathrm{C}$ and $\mathrm{pH} 6.7-7.3$. It is also known from other states of India; namely west Bengal (Gurney, 1906, 1907; MichaEL, 1968), Rajasthan (NAYAR, 1971), Bihar (NASAR, 1977), and Delhi (Brehm, 1950; George, 1966).

\section{Ceriodaphnia reticulata (JURINE) 1820}

(Figs. 25-26)

Measurements: Length $=0.86-0.91 \mathrm{~mm}$.

Locality: Pond Khera Jattan (Patiala) on 14.4.1968 and Bhupindra Sagar (Patran) on 19.5.1967.

Remarks: Head is compressed and rounded anteriorly, without any spine or horn. Eye and ocellus are quite prominent. Carapace is subovate with a deeply arched ventral margin, but dorsal margin less arched, (more or less straight in specimens without eggs). Superaposteal angle is ending in a small shell-spine. Postabdomen is with 7 unequal anal spines, distal being smaller than other, claw is provided with a proximal pecten of 5 teeth at some distance from the base.

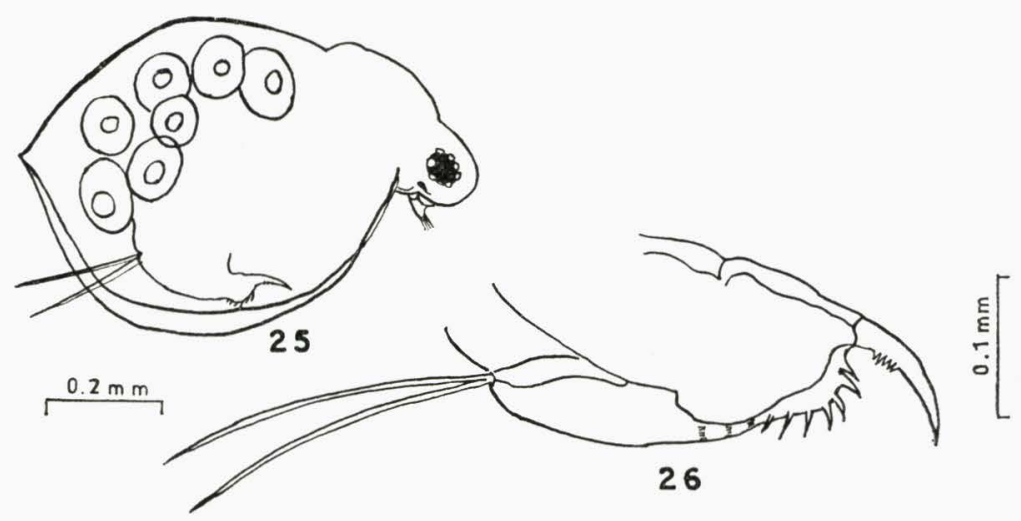

Ceriodaphnia reticulata

Fig. 25. Female, lateral view

Fig. 26. Female, postabdomen.

Ecology: This species is rather rare in occurrence as compared to $C$. cornuta. The present author collected it at a temperature of $26.0^{\circ} \mathrm{C}$ and $\mathrm{pH} 7.3$. This has also been reported from the ponds and lakes of other parts of India. NASAR (1977) reporter it from the ponds of Bhagalpur (Bihar) and NAYAR (1971) from Rajasthan. 


\section{References}

Arora, G.L., 1931. Fauna of Lahore, 2 Entomostraca (Water-fleas) of Lahore. Bull. Dept. Zool. Panjab Univ., 1: 62-100.

BAtTish, S.K. 1968. A study of the taxonomy and seasonal variation of Rotifers and Crustaceans. Approved for the M. Sc. (Hons. School), degree by Panjab University, Chandigarh, 199 pp. 000 .

1981. On some Chydorid and Macrothricid (Crustacea: Cladocera) from Punjab with the description of three new species. Researches on Crustacea, Carcinological Society of Japan, $11: 17-35$.

and Kumari, Parminder. Ecology of Cladocera of a Tropical Pond at RAQBA, LUD. HIANA. The Ecological Society of Japan (in press).

BAR, G. 1924. Uber Cladoceran von der Insel Ceylon. Jena Z. Naturw, 60: 83-126.

Branolova, Z. J., Z. Brandl and C. H. Fernando 1972. The Cladocera of Ontario with remarks on some species and distribution. Can. J. Zool., $50(1)$ : 1373-1403.

Brenm, V. 1936. Report on Cladocera. Yale North India Expedition. Mem. Conn. Acad. Sci., 10: 283-297.

- 1950. Contributions to the Freshwater Fauna of India, Part I and II. Recod. Ind. Mus., $48(1): 1-29$.

, 1953. Indishe Diaptomiden, Pseudodiaptomiden und Cladoceren. Ost. Zool. Z., 4: 241245.

Brooks, J.L., 1957. The systematics of North American Daphnia. Mem. Conn. Acad. Arst. Sci., 13: $1-180$.

Chakrabarty, R.D., Roy, R. and Singh, S.B. 1960. A quantitative study of the plankton and the physico-chemical conditions of the River Jamuna at Allahabad in 1954-55. Indian J. Fish., 6(1) : 186-203.

Daday, E. Von, 1910. Untersuchungen über die Süsswasser Mikrofauna Deutsch Afrikas. Zoologica, $59: 1-316$.

Das, S.M. and SRivastava, V.S. 1956. Quantitative studies on frewhwater plankton. I. Plankton of fish-tank in Lucknow, India. Proc. Nat. Acad. Sci. India, 36: 85-92.

and 1959. Studies on freshwater plankton. III. Qualitative composition and seasonal fluctuations in plankton components. Proc. Nat. Acad. Sci. India, 29: 174-189.

Fernando, C. H. 1980. The Freshwater Zooplankton of Sri Lanka, with a discussion of Tropical Freshwater Zooplankton Composition. Int. Rev. ges. Hydrobiol., 65(1) : 85-125.

FRYER, G. 1957. Freeliving fresपwater Crustacea from Lake Nyasa and adjoining waters. Part II. Cladocera and Conchostraca. Arch. f. Hydrobiol., $53(2)$ : 223-239.

Ganapati, S. V. 1943. An ecological study of a garden pond containing abundant zooplankton. Proc. Indian Acad. Sci., 17: 41-58.

GEorge, M. G. 1966. Comparative plankton ecology of fish tanks in Delhi, India. Hydrobiologia, $27(182): 81-108$.

GuRnEy, R. 1906. On some freshwater Entomostraca in the collection of the Indian Museum, Calcutta. J. Asiat. Soc. Bengal, 2(7): 263-281.

- 1907. Further notes on Indian freshwater Entomostraca. Rec. Ind. Mus., 1: 21-23.

, 1916. On some freshwater Entomostraca from Ceylon. Proc. Zool. Soc., London, 00: 333-343.

Hebert, D.N. 1977. A Revision of the Taxonomy of the genus Daphnia (Crustacea: Daphnidae) in South-Eastern Australia. Aust. J. Zool., 25: 371-398.

Johnson, D.S. 1952. The British species of the genus Daphnia. Proc. Zool. Soc. London, 122: $435-462$.

Khan, A. and QAYyum, A. Siddiqui, 1978. Seasonal changes in the limnology of a perennial fish pond at Aligarh. Indian J. Fish, $21(2): 463-478$. 
LeodolfF, C. J. 1964. The function of Cladocera in Oxidation ponds: 307-317, in: Advances in water pollution research (ed. Jaag) Pergamon Press.

Mamaril, A.C.Sr. and Fernando, C.H. 1978. Freshwater Zooplankton of the Philippines (Rotifera, Cladocera, and Copepoda). Natural and Applied Science Bulletin, 30(4): 109-221.

Michael, R. G. 1968. Studies on the zooplankton of a tropical fish pond. Hydrobiologia, 32 (1 \& 2) : 47-468.

Moitra, S.K. and Bhattacharya, B.K. 1965. Some hydrological, factors affecting plankton production in a fish pond in Kalyani, W. Bengal, India. Ichthyologica, 4(1-2): 8-12.

NASAR, S. A.K. 1975. Seasonal variations in the physico-chemical and biological properties of a tropical shallow pond. Jap. J. Ecol., 24 (4) : 255-259.

- 1977. The zooplankton fauna of Bhagalpur (Orissa) II. Cladocera. Researches on Crustacea, Carcinological Society of Japan, 08: 32-36.

NAYAR, C.K. G. 1971. Cladocera of Rajasthan. Hydrobiologia, 37(3-4) : 500-529.

Pruthi, H.S. 1933. Studies on bionomics of freshwaters of India. I. Seasonal changes in the physical and chemical conditions of the water in the Tank in Indian Museum Compound. Int. Rev. ges. Hydrobiol., $26:$ 46-47.

SARS, G. O. 1903. Freshwater Entomostraca from China and Sumatra. Arch. Mat. Naturv., 25(8) : 1-44.

1917. The freshwater Entomostraca of Capa Province. Ann. South. African Museum. $1: 333-350$.

SingH, R.S. 1982. Systematics and ecology of the Aquatic Crustacea of Rewa. Geobios new Reports, 1: 53-54.

Sreenivasan, A. 1967. Application of limnological and primary production studies in fish Culture. FAO FISH REP. No. 3, 44 : 104-113.

- 1972. Limnology of a seepage type impoundment odathurai tank. J. Inland Fish. Soc. India, $4: 162-168$.

—, 1974. Limnological features of a tropical impoumdment, Bhavanisagar reservoir (T. N.), India. Int. Rev. Ges. Hydrobiol., 59(3) : 327-342.

VAsisht, H.S. and DhiR, S.C. 1970. Seasonal distribution of freshwater zooplankton of four tanks, Chandigarh. Ichthyologia 10(1-2) : 44-56.

VASS, K.K. and ZUTSHI, D.P. 1980. Limnological studies, morphometery and physical features of Dal lake, Kashmir, India. J. Inl. Fish. Soc. India, 11(1): 12-21.

要 約

プンジャブ地方 (インド) に生息する 9 種のミジンコ類 (ミジンコ科): Daphnia lunholtzi, D. magna オオミジンコ, D. similis, simocephalus acutsrostratus, S. expinosus トゲオカメ ミシシンュ, S. vetulus オカメミジンュ, Scapholebris kingi, C. reticutata について, これら の生態と形態について記載した。 